\title{
Problem of heightened content of manganese in ponds
}

\author{
E. Arystarhova, \\ Candidate of Biological Sciences \\ Institute of Agroecology and Natural Resources of NAAS
}

The purpose. To determine features of seasonal changes of density of manganese and to analyze the possible causes of its fluctuation in ponds. Methods. Water samples are taken from drawoff Otsechnoye of river Teterev and clear-water basins during 2006-2008. Density of manganese is determined using colorimetric method. Results. In study the problem of overflow of maximum concentration limit (MCL) of manganese in water of drawoff (especially in summer months) is considered and ways of its solution are offered. Conclusions. Revealed in drawoff Otsechnoye of river Teterev in 2006 - 2008 and existing till now overflow of maximum concentration limit of manganese on the background of its significant seasonal fluctuation should be reduced by use of aquatic organismsconcentrators and seizing the receipt in drawoff of the residues of manganous microfertilizers, humus matters, etc.

Key words: manganese, seasonal fluctuation, waters of drawoff, clear-water basins, drinking water, agricultural sources of manganese.

Anthropogenic eutrophication is an impetus to a number of negative processes that are triggered in aquatic ecosystems along with the "flowering" of water and lead to so-called self-pollution. The main reason for eutrophication is the enrichment of water with biogenes due to washing out of fertilizer fields, the flow of livestock farms and communal waste water. Biogenic elements provoke the active growth of planktonic algae groups, especially blue-green (cyanobacteria), which have an allelopathic effect in relation to other phytoplankton groups. With the active development of cyanobacteria secreting toxins, in many reservoirs the growth of diatoms, greens and other groups, which resolve to decompose, polluting the water with harmful substances, ceases. Almost always among them are the compounds of manganese, which, being released from organic complexes in the composition of algae, enter into water in the form of ions $[3,5]$.

In addition to biotic origin, the accumulation in the reservoirs of manganese compounds, may also be man-made [5, 7]. In some areas, manganese falls into surface waters as a result of leaching iron ore ores and other minerals, which it includes (pyrolusite, psilomelan, brownite, manganite, black water). Manganese compounds are deposited in reservoirs with sewage from manganese concentrating factories, metallurgical plants, chemical industry enterprises and mine waters. However, in the final analysis, manganese is actively involved in biogeochemical colloidal activities involving aquatic organisms, primarily phytoplankton [3,5].

Many studies are evidence that manganese being a heavy metal, is a threat to biota because of its acute toxicity and ability to accumulate in the reservoirs to dangerous levels. In the process of oxidation and adsorption on suspended in water, organic and inorganic particles of manganese turns into forms that accumulate in the sediments, causing secondary contamination of water bodies. Exit from the layers of layers significantly impairs the quality of water, posing a real threat to drinking water supply [5, 13].

Excessive flow of manganese in the composition of drinking water in humans and animals initially causes damage to the central nervous system, eventually disrupt pulmonary, cardiovascular and hepatobiliary systems and ultimately can lead to such long-term effects as allergenic, mutagenic and carcinogenic effects. That is why the concentration of manganese in water should be rigidly normalized $[5,7]$. 
However, in some of the literature shows that aquatic ecosystems manganese values is not limited to its negative effect $[5,10]$. It is known that this item has a special status. manganese belongs to the essential trace elements, the inadequate receipt of which in the body leads to a number of diseases. A significant amount of biochemical reactions and processes under the manganese deficiency are suppressed $[3,10]$. It promotes the recycling of carbon from $\mathrm{CO}_{2}$ in carboxylation reactions at higher and lower plants, increases the rate of photosynthesis, participates in the process of recovery and nitrate nitrogen assimilation of plant organisms. It also provides the transition of active Fe (II) to Fe (III), which protects the cell from toxic influences, accelerates the growth of plants. Manganese is also part of many enzyme systems that regulate tissue respiration and provide the biosynthesis of proteins, lipids and polysaccharides in humans and animals $[5,10,12]$.

Consequently, in aquatic ecosystems, manganese generally plays a positive role, has important ecological and physiological functions. However, the excess of its content negatively affects not only the state of hydrobionts populations and violation of the ecological balance of reservoirs, but also can significantly increase the toxicity of water, making it unsuitable, even after cleaning, for human and animal use. It is therefore important to follow the fate of manganese in a water environment.

Goal of research - to determine the seasonal changes in the manganese concentration and to analyze the possible causes of its fluctuations in the reservoirs.

Methods. The research was conducted with the participation of employees of Municipal Enterprise "Zhytomyrvodokanal", using the commonly used methods [6]. Sampling of water (1 dm3) was carried out from the water intake of the Teteriv river and the clean water reservoirs (CWR 5000 CBM) three times a month during 2006-2008. The concentration of manganese in water samples was determined by the colorimetric method [6,7]. The content of manganese in the drinking water reservoir and its seasonal variations were compared with the corresponding changes in the manganese content in drinking water. The data batch was executed using the standard Microsoft Office Excel 2003.

Results. Since effluents from chemical, metallurgical processing and other enterprises that contain manganese and its compounds in the Teteriv river reservoirs available, may suggest that the anthropogenic contribution to give humic substances washed precipitation of farmland and private farms [1]. It is known that manganese is introduced into the soil mainly in the form of manganese micronutrients exposed biohidrohenniy accumulation. At the same time, he, like other trace elements, has a high migration ability. For example, the sod podzol soils Polissya from each hectare agricultural lands washed away annually about $408 \mathrm{~g}$ manganese - the largest number of trace elements (228 g of zinc, $25 \mathrm{~g}$ of copper, $5 \mathrm{~g}$ of boron, etc.) [2]. In addition, high natural content of manganese is observed in almost all water bodies of the Polissya area. This is due to its leaching compounds from the forest floor, peat and iron-manganese nodules soil $[1,4,5]$. That forestry, bogs and ponds pools Polissya proximity to them illuvial horizons of sod podzol soils that are typical for the region will always carry a risk of water pollution excessive manganese compounds. This is especially true for ponds with slower water exchange, which include reservoirs. Therefore, there are clear reasons for the high content of manganese in the water intake Vidsichne of Teteriv river. At the same time, significant variations in its concentration in the waters throughout the year can be explained biotic changes taking place in different seasons

In our studies in the spring of 2006 and 2008, during an outflow of water, an increase in water manganese concentration was observed in excess of the norm 2-4 times. And in the summer of 20062008 , with an increase in the temperature of air and water, its number increased by 8-10 times relative to the MPC (MPC per manganese ion - $0.1 \mathrm{mg} / \mathrm{dm} 3$ ) (Figure 1): 
$\mathrm{mg} / \mathrm{dm}$

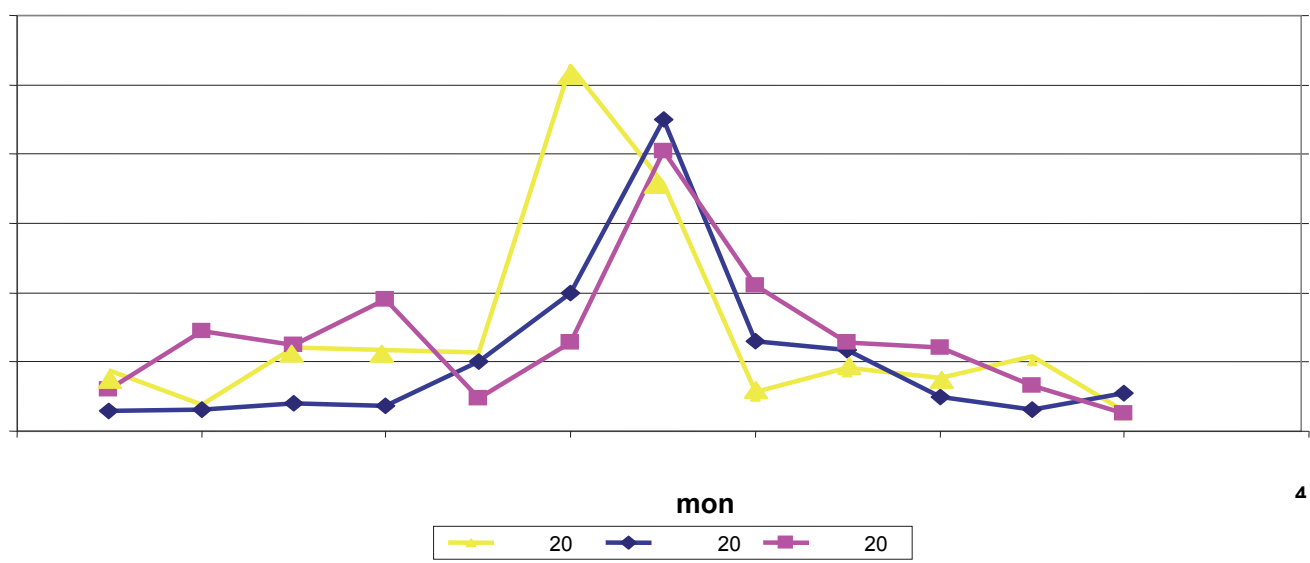

Fig. 1. Concentration of manganese in waters of the Vidsichne water intake of Teteriv river

Explain this phenomenon only by the presence of manganese in the composition of humus substances and its natural occurrence in the reservoir is impossible. In this regard, it is advisable to mention the important biotic component, that is, the participation of hydrobionts in the manganese metabolism: a significant amount of it enters the aquatic environment during the abatement and decomposition of aquatic organisms, especially blue-green and diatoms, to a lesser extent - aquatic plants [5, 7]. Indeed, in our studies, diatoms, actively developing in the spring months of 2006-2008 with a peak in March, were almost completely decomposed in May. Accordingly, in July 2006-2007 and in June 2008, peaks of the increase in the content of manganese ions in the water intake could be observed. This difference between years is explained by the fact that in 2008, as a result of an increase in the average monthly and June temperature in comparison with previous years, the group of blue-green algae began their active growth not in the previous years, from the second half of July, but from the beginning of June. In the following "postpone" months, the concentration of manganese decreased, which coincided with the growth of the green groups and especially the rapid increase in the number of blue-green algae. It is known that cyanobacteria can accumulate in trace amounts of trace elements and thus reduce their concentration in water $[7,9,11]$. It is these features that can be explained by the decrease in Manganese content in July and August.

The rise of temperature in summer was accompanied by a decrease in the concentration of dissolved oxygen (DO) in water of water intake. That is, the oxidation of manganese at the proper level under such conditions was not carried out and most likely there was a process of transition from sludge to the water column. This could have been one of the causes of excessive concentration of manganese in water. As the temperature dropped in autumn and the rise of the DO, the oxidative-reducing potential of the reservoir was normalized, which also had a positive effect on the level of content in the water of manganese. Even despite the prolonged process of decomposition of blue-green algae, which began in October and ended only in the months of December, the manganese content was no longer subject to rapid increase and did not acquire such a high level. Particularly, manganese compounds released into water during rotting of blue-green could be disposed of by diatoms, which again began to appear with a decrease in water temperature. However, their main part as a result of oxidation, had to eventually find itself in the sludge deposits. This assumption is confirmed by the literature data, according to which the concentration of manganese in water decreases both as a result of the utilization of their algae, and as a result of the oxidation of $\mathrm{Mn}$ (II) to $\mathrm{MnO}_{2}$ and other oxide deposited in the precipitate $[8,9]$.

In the water intake according to the water quality index, the content of manganese belonged to the 3rd class. After water treatment, he switched to the 2 nd grade, but the changes observed in the water of the water intake were reflected also in drinking water (Figure 2). 
$\mathrm{mg} / \mathrm{d}$

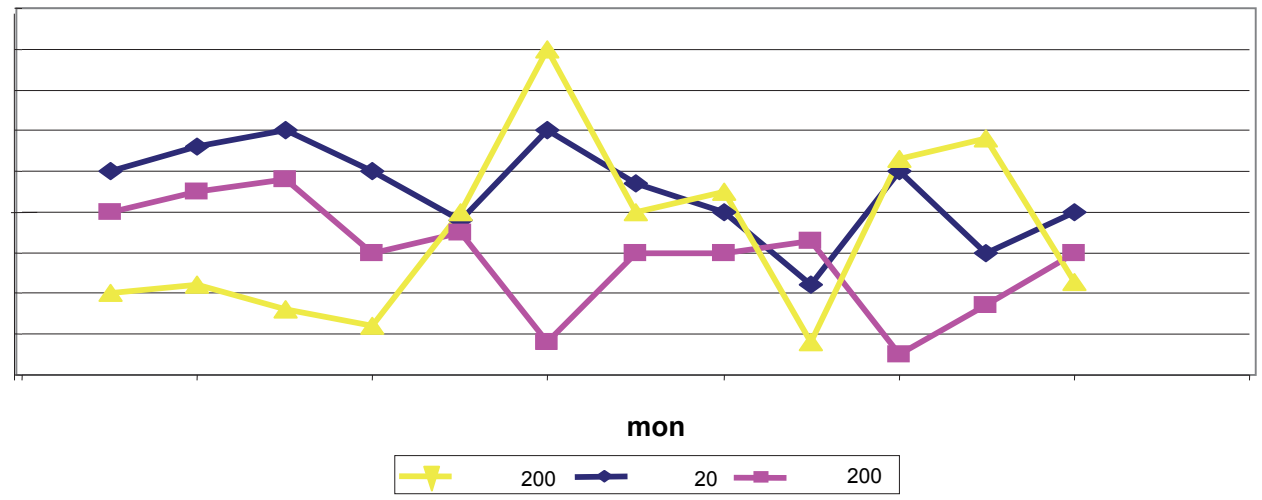

Fig. 2. Concentration of manganese in water of the ME "Zhytomyrvodokanal"

In drinking water, clearly marked periods of particularly high manganese concentration were formed: May-August and October-November. In these terms manganese content significantly exceeded the norm $(0.05 \mathrm{mg} / \mathrm{dm} 3)$ and drinking water had a metallic taste and high coloring.

To normalize the content of manganese in drinking water in 2012 when the second water chlorination was replaced by hypochlorination: sodium hypochlorite was more powerful oxidizer than liquid chlorine. However, until now, the problem of the increased concentration of manganese in the water of the intake water, which has a tendency to increase. For its solution, it is expedient to apply biotechnological methods involving plant and animal concentrating organisms. Fish, shellfish, higher plants, bacteria and algae can be used [1, 12-14]. The literature describes the cyanobacterium Spirulina platensis ability to absorb heavy metals on the cell surface and translate them into nontoxic chelated form, including cyanobacteria classified batteries with manganese accumulation threshold in the cells about $10 \mathrm{mg} / \mathrm{g}$ dry weight $[7,9,10]$. That is, the use of the culture of cyanobacteria can simultaneously reduce the concentration of manganese in water, to ensure its detoxification as a heavy metal.

In addition to concentrating manganese in the body of hydrobionts, there are also ways of intercepting it when it comes from the catchment area in the reservoir. Rinse water often contains residues of fertilizers, humus and other sources of manganese. For their mandatory detention should be planting on the banks of shrubs and trees (calluna, willow, wicker, hazel, etc.) And periodic removal of undergrowth air-water macrophytes (typha, sagittaria, manna grass, reeds, etc.). A very effective way to reduce migration of manganese compounds in agricultural landscapes and water bodies considered the use of green fertilizers (seeding, crop, winter grains) [2, 9, 14].

These measures will be useful not only to lower water concentrations of heavy metals, including manganese compounds, but also to promote the release of the aquatic environment from excessive amounts of certain other pollutants (nitrates, nutrients, radionuclides, etc.).

\section{Conclusions}

In the water intake section of Teterev river and in the drinking water at the Municipal Enterprise "Zhytomyrvodokanal" in 2006-2008, an exceedance of the manganese concentration regulation was detected against the backdrop of its significant seasonal fluctuations. Extremely high manganese content in summer was contributed to the rise in water temperature and a decrease in the concentration of DO in the water intake, which intensified the release of manganese compounds from sludge deposits and diatoms during their decomposition. In order to reduce the content of manganese to the regulatory value in drinking water at the water supply canal, since 2012, liquid chlorine has been replaced by sodium hypochlorite. To solve the problem of reducing the content of manganese compounds in the water intake, it is expedient to use hydrobionts-concentrators. Particular attention deserves the removal of anthropogenic sources of manganese - preventing the flow of water from humus substances from 
agrolandscapes (application of green fertilizers, planting bushes and trees, extraction of macrophyte thickets).

\section{Bibliography}

1. Hidrokhimiia ta radioheokhimiia richok i bolit Zhytomyrskoi oblasti/S.I. Snizhko, O.O. Orlov, D.V. Zakrevskyi ta in. ; za red. S.I. Snizhka, O.O. Orlova. - Zhytomyr: Volyn, 2002. - 264 s.

2. Dovban K.Y. Zelenoe udobrenye v sovremennom zemledelyy: voprosы teoryy y praktyky/K.Y. Dovban. - Mynsk: Belorus. nauka, 2009. - $404 \mathrm{~s}$.

3. Zapolskyi A.K. Ochystka vodы koahulyrovanyem : monohraf./A.K. Zapolskyi. - Kamenets-Podolskyi : ChP «Medoborb»-2006», 2011. - 296 s.

4. Polupan N.I. Vyznachnyk ekoloho-henetychnoho statusu ta rodiuchosti gruntiv Ukrainy: navch. posib./N.I. Polupan, V.B. Solovei, V.I. Kysil, V.A. Velychko- K.: Koloobih, 2005. - 304 s.

5. Romanenko V.D. Osnovы hydroэkolohyy : uchebn. dlia studentov vыsshykh uchebnыkh zavedenyi/V.D. Romanenko. - K. : Heneza, 2004. - 664 s.

6. Unyfytsyrovannыe metodы analyza vod/Pod red. Yu.lu. Lure. - M.: Khymyia, 1973. - 376 s.

7. Chernykova, A.A. Nakoplenye medy y marhantsa $v$ kletkakh tsyanobakteryy Spirulina platensis/Chernykova A.A. - dys. ... kand. byol. nauk. - M., 2009. - 150 s.8. A new paradigm manganesesuperoxide dismutase influernces the production of $\mathrm{H}_{2} \mathrm{O}_{2}$ in cells and thereby their biological state/G.R. Buettner, C.F. Ng, M.Wang et al.//Free Radic Biol. Med. - 2006. - Vol. 41. - P. 1338-1350.

9. Arunakumara K.K.I.U., Heavy metal bioaccumulation and toxicity with special reference to microalgae/K.K.I.U. Arunakumara, Z. Xuecheng//J. Ocean Univ. Chin. - 2008. - Vol. 7. - P. 60-64.

10. Cyanobacterial photosystem II at 2.9-A resolution and the role of quinones, lipids, channels and chloride/A. Guskov, J. Kern, A. Gabdulkhakov et al.//Nat. Struct. Mol. Biol. - 2009. - Vol. 16 (3). - P. 334342.

11. Phytoremediation of heavy metal polluted soils and water: Progresses and perspectives/M.I. Lone, Z. He, P.J. Stoffell, X. Yang//J. Zhejiang. Univ. Sci. B. - 2008. - Vol. 9. - P. 210-220.

12. Responses of Trapa natans $L$. floating laminae to high concentrations of manganese/C. Baldisserotto, L. Ferroni, E. Anfuso et al.//Protoplasma. - 2007. - Vol. 231. - P. 65-82.

13. Screening the phytoremediation potential of desert broom (Baccharis sarothroides Gray) growing on mine tailings in Arizona. USA./N. Haquea, J.R.Peralta-Videab, G.L.Jonesc et al.//Environ. Pollut. 2008. - Vol. 153. - P. 362-368.

14. Yan-de J. Role of soil rhizobacteria in phytoremediation of heavy metal contaminated soils/J. Yande, H.E. Zhen-li, Y.J. Xiao-el//Zhejiang. Univ. Sci. B. - 2007. - Vol. 8. - P. 192-207. 